\title{
Aboriginal North American
}

National Cancer Institute

\section{Source}

National Cancer Institute. Aboriginal North American. NCI Thesaurus. Code C159826.

Denotes any of the indigenous people who lived in North America at the time Europeans reached the continent, including Native American, First Nations, Inuit, and Metis people. 